\title{
ADVISORY COUNCIL ON SCIENTIFIC POLICY
}

\begin{abstract}
$A^{\mathrm{p}}$ PPENDED to the seventeenth annual report of the Advisory Council on Scientific Policy* are the usual tables to be found in recent reports giving details of support of research at universities and colleges of advanced technology by the Research Councils, Government expenditure on civil research, and an analysis of the expenditure and staff of the Research Councils. Figures are also appended for science and mathematics graduate teachers in grant-aided schools and establishments, for first degrees and diplomas awarded in science and technology in 1962-63 and new membership of scientific and technological professional institutions. In view of tendentious questions asked in Parliament, the Advisory Council has also done well to append the memorandum of advice regarding a World Health Research Centre sent to the Minister for Science in February 1964. In addition to topics discussed elsewhere (see p. 319 of this issue), the main report also refers briefly to the International Biological Programme proposed by the International Council of Scientific Unions, and to the position of research in oceanography and marine biology, particularly in the laboratories of the Fisheries Department.

Expenditure by the Research Councils in support of research at universities and colleges of advanced technology is estimated at $£ 12 \cdot 1$ million in 1963-64 and $\mathfrak{1 4 . 8}$ million in 1964-65, compared with expenditure from the Exchequer grant to universities through the University Grants Committee of $£ 31$ million and $£ 37 \cdot 1$
\end{abstract}

-Annual Report of the Advisory Council on Scientific Policy, 1963-1964. Pp. vi + 48. (Cmnd. 2538.) (London: H.M.S.O., 1964). 48, net. million, respectively. Of the $£ 12 \cdot 1$ million, $£ 5 \cdot 2$ million was on research grants, $£ 2.5$ million on research units within universities and colleges of technology, and $£ 1 \cdot 6$ million on research units associated with them; and $£ 2.4$ million on postgraduate studentships and fellowships : for 1964-65 the corresponding figures are estimated as $£ 6.8$ million, $£ 2.7$ million, $£ 1.57$ million, and $£ 2.8$ million, respectively. Government expenditure on civil research is estimated at $£ 174$ million in $1963-64$ and $£ 204.5$ million in $1964-65$; of these totals, $£ 14 \cdot 1$ million and $£ 15.8$ million, respectively, are on agriculture, forestry, fisheries and food; $£ 41.5$ million and $£ 49.7$ million, respectively, on industry and communications; $£ 7.7$ million and $£ 9.7$ million on medicine and health; $£ 2.3$ million and $£ 2.28$ million on overseas research; $£ 52.8$ million and $£ 56.9$ million on nuclear science; $£ 31.2$ million and $£ 37 \cdot 6$ million on universities and learned societies; and $£ 24.6$ million and $£ 32.5$ million were spent in other ways, mainly through the Ministry of Aviation. Science and mathematics graduate teachers in grantaided schools and establishments in England and Wales increased from 20,870 in 1962 to 22,121 in 1963 ; corresponding figures for Scotland being 5,255 and 5,338. In 1962-63, 7,728 first degrees and diplomas were awarded in science faculties and 3,983 in technology faculties, compared with 7,080 and 4,188 in $1961-62 ; 1,073$ diplomas in technology were awarded in 1963-64, compared with 927 in 1962-63 and 620 in 1961-62. New membership of scientific and technological professional institutions increased from 11,057 in 1962 to 12,135 in 1963 .

\section{BRITISH AID TO THE WEST INDIES}

\begin{abstract}
TN Aid to the West Indies*, Mr. D. J. Morgan surveys attitudes and needs for the Overseas Development Institute seeking to elucidate obstacles to the effective use of British aid. An introductory chapter is followed by successive surveys of Bermuda and the Bahamas; Jamaica, Trinidad and Tobago; British Guiana; and Barbados, the Leeward and Windward Islands. Finally, some proposals are advanced for changes to maintain and increase the effectiveness of Britain's aid, including an immediate conference on the subject. The survey was assisted by a six-week visit to the West Indies during February-March 1964, in which problems of obtaining and using British aid were discussed.

Mr. Morgan found a general feeling in the West Indies that over the past decade or so interest has passed from their problems to those of Africa, and although bilateral aid from the United Kingdom to the West Indies has increased from $£ 4 \cdot 38$ million in $1945-46$ to $1956-57$ to E14.95 million in $1960-63$, in the same period the proportion going to the West Indies has fallen from 10 per cent to $\mathbf{7 \cdot 4 5}$ per cent. Nevertheless, although no single development plan in the West Indies was wholly financed from Colonial Development and Welfare Funds in the late 1950's, four of the plans for 1960-64 were. Research assistance provided through the Department of Technical Co-operation is still predominantly for Africa and the West Indies, with the main emphasis in the fields of natural resources and medicine. Apart from the effect of price changes and, to a limited extent, the collapse of the
\end{abstract}

- Overseas Development Institute, Ltd., Aid to the West Indies: a Survey of Attitudes and Needs. By D.J. Morgan. Pp.56. (London: Overseas Development Institute, 1964.) 88. $6 d$.
Federation, there is little evidence of neglect. However, Mr. Morgan suggests that the relatively high per capita income found side by side with high unemployment calls for special assistance. The grant-in-aid system appears to sap local initiative, while there are serious delays in aid administered through London as compared with American and United Nations programmes.

Accordingly, a regional aid office is suggested to administer Britain's contributions and regional programmes in agriculture, medicine, education, technical training and rural credit, and this should be a major item on the agenda for the proposed conference.

The main emphasis of the survey is on such regional schemes and programmes for medicine, agriculture, education, technical training, development banking, etc. While the people of the West Indies receive more aid from Britain than almost any other part of the Commonwealth- $£ 8$ million in $1962-63$, an annual average of more than $£ 3$ a head for the past three years, apart from a substantial subsidy through the Commonwealth Sugar Agreement-more information about the programme in the area would probably make it more effective. Technical assistance to the West Indies in 1961 was $£ 461,400$, rising to $£ 713,000$ in 1963 , compared with bilateral totals for all countries of $£ 15.4$ million and $£ 24.3$ million, respectively. Mr. Morgan suggests that these figures indicate a relative neglect of the West Indies in technical assistance.

The survey is the first of those from the Overseas Development Institute concerned primarily with the recipient and not the donor aspect of British aid. It lacks something of the clarity which has characterized earlier reports from this Institute. 